\title{
Statyba
}

\section{THE INTERACTION OF SOUND FIELDS SEPARATED BY THE RESONANT SUSPENDED CEILING}

\section{Stauskis}

To cite this article: V. Stauskis (1997) THE INTERACTION OF SOUND FIELDS

SEPARATED BY THE RESONANT SUSPENDED CEILING, Statyba, 3:11, 90-95, DOI:

10.1080/13921525.1997.10531359

To link to this article: https://doi.org/10.1080/13921525.1997.10531359

曲 Published online: 26 Jul 2012.

Submit your article to this journal $\pi$

山 Article views: 39

4 Citing articles: 1 View citing articles 준 


\section{THE INTERACTION OF SOUND FIELDS SEPARATED BY THE RESONAN' SUSPENDED CEILING}

\section{Stauskis}

\section{Introduction}

Designing of multipurpose halls almost always involves installation of suspended ceiling. Such ceiling exerts considerable influence on the hall acoustics. It may consist of even planes or structural elements with varied geometrical parameters. Sound may be reflected from such ceiling planes to the listeners' seats directionally or diffusely. Such subjective indicator of musical sound as the sound clarity index largely depends on the suspended ceiling. When forming such ceiling, slits of various form and width may be left between the ceiling planes. Therefore it is necessary to estimate the effect of such slits on the acoustic indicators of the hall.

It has been established in [1] that the reverberation time is markedly reduced by such ceiling at low frequencies. Depending on the width of the slits and the distance between the ceiling and the rigid surface, the absorption coefficients of the hall and the general hall absorption may be increased or reduced. With slits between the planes of the suspended ceiling, an interaction of the sound energies of two bodies of air, the one under and the one above the suspended ceiling, will take place.

The purpose of this work is to establish both theoretically and experimentally the interaction between the sound energies of the upper and the lower bodies of air in the hall with suspended ceiling and slits between the planes as well as to determine the effect produced on the energies by changing geometrical and acoustic parameters of the ceiling.

\section{Theory}

A number of authors have investigated the theoretical problems of the interaction of the sound fields of acoustically-interrelated premiscs, both in the steady state and the transitional regime. V. Furduyev [2] and G. Goldberg [3] studied theoretically the changes in the reverberation time in acoustically-interrelated premises. Kh. Shchirzhecki [4] investigated theoretically the time-dependence of the sound field attenuation in the acoustically-interrelated large bodies separated by a wide opening. H. Kuttruff [5] was interested in the same dependence of three premises linked by openings. However, no experimental results are presented in these works. The frequency-dependence of the interacting sound fields and the change in these fields depending on varied geometrical parameters of the openings were not examined.

The suspended ceiling having reclangular-shaped slits located crosswise in respect of the hall divides the hall into two bodies: the upper body above the suspended ceiling and the lower one under it. After impulse excitation of the sound ficld in the hall, i.e. in the lower body, the sound waves will reach the upper body through the slits, thus forming a sound field in the upper body as well. Part of the energy will return back to the hall, i.c. to the listeners, through the same slits; then the sound reflected from the lloor and other planes will return to the upper body again. The process will occur over and over. Thus the muflling sound field in the hall will be influenced by the muffling sound field above the suspended ceiling and vice versa. The attenuation of the sound field above the ceiling will have an impact on the acoustic indicators of the hall. The process is schematically depicted in Fig 1.

A case will be examined when the regime is settled both in the lower body, marked as $V$, and the upper body, marked as $\mathrm{V}$. The sound source $\mathrm{P}$ is in the lower body $\mathrm{V}$. The interaction of both bodies will be considered to occur through the opening, which is equal to the overall area of the slits between the ceiling planes. In case of an ideally diffusive sound liek in both bodies, the steady-state energy in the lower body may be written as follows:

$$
E_{01}=\frac{4 P_{a}}{C\left(\alpha_{1} S_{1}+F\right)\left(1-Q_{1} Q_{2}\right)}=X(1)+X(2)
$$




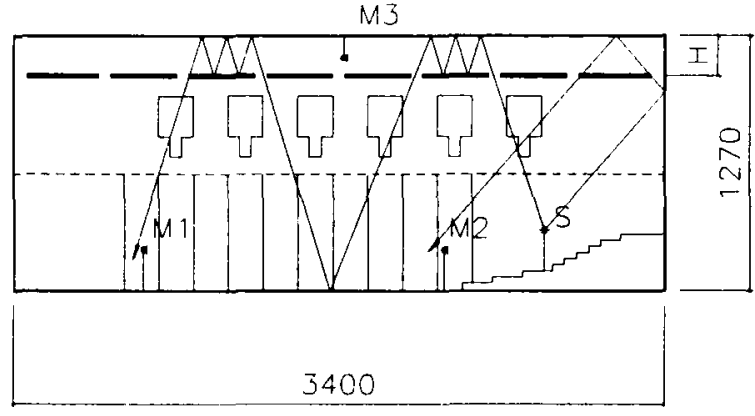

Fig 1. The distribution of the first sound reflections in the lower and upper bodies of the hall

and in the upper body:

$$
E_{02}=E_{01} Q_{2}=Y(1)+Y(2)
$$

where $P_{a}$ is the power of the source; $c$ is the sound velocity in the air; $\alpha_{1}, S_{1}$ are the absorption coefficients of the lower body and the area of surfaces; $F$ is the overall area of all slits in the ceiling; $X(1)$, $X(2), Y(1)$ and $Y(2)$ are the coefficients to be found; $Q_{1}$ and $Q_{2}$ are the coefficients of link between the two bodies.

The link coefficient for the lower body is equal

$$
Q_{1}=\frac{F}{\alpha_{1} s_{1}+F} .
$$

The link coefficient for the upper body is equal

$$
Q_{2}=\frac{F}{\alpha_{2} S_{2}+F} .
$$

When $t=0$, i.e. when the sound source has ceased operating and the reverberation process in both bodies has a perfectly exponent character, the sound field attenuation in both bodies will depend on the sound attenuation constants in these bodies. Then the sound energy in the lower body may be expressed as follows:

$$
V_{1} \frac{d E_{1}}{d t}=-\frac{c \alpha_{1} S_{1}}{4} E_{1}-\frac{c F}{4} E_{1}+\frac{c F}{4} E_{2} .
$$

The sound energy in the upper body may be expressed as:

$$
V_{2} \frac{d E_{2}}{d t}=-\frac{c \alpha_{2} S_{2}}{4} E_{2}-\frac{c F}{4} E_{2}+\frac{c F}{4} E_{1} .
$$

The first member in these formulas describes the absorbing energy in the upper and lower bodies, the second member - the energies outgoing from respective bodies, and the third member - the energies returning to respective bodies.

The following markings will be introduced:

$$
\begin{gathered}
\gamma_{1}=\frac{c \alpha_{1} s_{1}}{4 V_{1}} ; \gamma_{2}=\frac{c \alpha_{2} S_{2}}{4 V_{2}} ; \\
\gamma_{12}=\frac{c F}{4}\left(\frac{1}{V_{1}}+\frac{1}{V_{2}}\right)
\end{gathered}
$$

Then the energy in the lower body will be equal to:

$$
E_{1}=X(1) e^{-\delta_{1} t}+X(2) e^{\delta_{2} t}
$$

The energy in the upper body will be equal to:

$$
E_{2}=Y(1) e^{-\delta_{1} t}+Y(2) e^{\delta_{2} t}
$$

where $\delta_{1}$ is the constant of the attenuation of the lower body, which is equal to

$$
\delta_{1}=a\left(1-\sqrt{1-\frac{b}{a^{2}}}\right) .
$$

The upper body attenuation constant $\delta_{2}$ is equal to:

$$
\delta_{2}=a\left(1+\sqrt{1-\frac{b}{a^{2}}}\right) .
$$

The following markings will be introduced:

$$
\begin{gathered}
a=\frac{1}{2}\left(\gamma_{1}+\gamma_{2}+\gamma_{12}\right) \\
b=\gamma_{1} \gamma_{2}+\gamma_{1} \frac{\gamma_{12}}{1+\frac{V_{1}}{V_{2}}}+\gamma_{2} \frac{\gamma_{12}}{1+\frac{V_{1}}{V_{2}}}
\end{gathered}
$$

Then the changes of the above-mentioned energies in the lower body may be calculated from the following formula:

$$
Y(1)=X(1)\left[1+\frac{\gamma_{1}}{\gamma_{12}}\left(1+\frac{V_{1}}{V_{2}}\right)-\frac{\delta_{1}}{\gamma_{12}}\left(1+\frac{V_{1}}{V_{2}}\right)\right]
$$

The energy changes in the upper body will be calculated from the formula

$$
\begin{aligned}
& Y(2)=X(2)\left[1+\frac{\gamma_{1}}{\gamma_{12}}\left(1+\frac{V_{1}}{V_{2}}\right)-\frac{\delta_{2}}{\gamma_{12}}\left(1+\frac{V_{1}}{V_{2}}\right)\right] . \\
& \text { If } V_{1} \gg V_{2}, \text { then } \delta_{1} \approx \gamma_{1} \text { and } \delta_{2} \approx \gamma_{2} .
\end{aligned}
$$




\section{Results}

The interaction of the sound fields should, first of all, exert effect on the reverberation times of both bodies. When conducting experiments with the hall model scaled 1:25 [2], all walls and the floor in the lower body were made of sound-reflecting materials and only the orchestra rise $119 \mathrm{~m}^{2}$ in area was of sound-absorbing materials. All planes of the upper volume were made of materials reflecting sound well, just as the ceiling itself. The results of the investigations are presented in Fig 2.

When the hall has no suspended ceiling, its reverberation time is long and it rapidly decreases with the increase in frequency. In the case under consideration, the ceiling was installed at the distance of $1 \mathrm{~m}$ from the rigid surface. Then the lower body makes up $8273 \mathrm{~m}^{3}$, while the volume of the upper body is $748 \mathrm{~m}^{3}$ only. In such case, the reverberation times of both bodies should differ greatly, since these times are largely dependent on the volume of the hall. Quite to the contrary, no such results were obtained during the investigations. Though the lower body is 11 times as large as the upper body, their reverberation times are almost equal all over the frequency range. At $100 \mathrm{~Hz}$ and $160 \mathrm{~Hz}$, the reverberation time of the upper volume is even longer than the reverberation time of the large lower body. This shows that there is an interaction between the energies of both volumes. The same regularity is also observed when the suspended ceiling is at the distance of $4 \mathrm{~m}$ from the rigid surface.

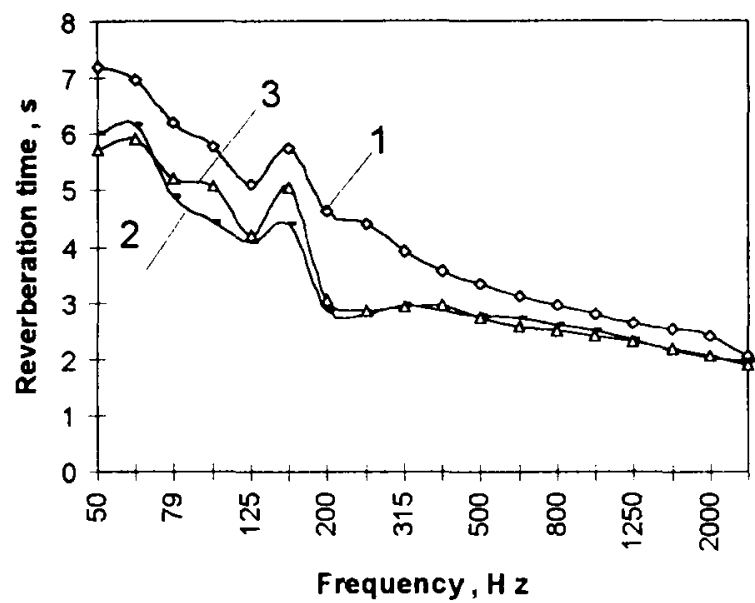

Fig 2. The frequency-dependence of the reverberation time in the halls with varied volumes. 1 - without suspended ceiling, $V=9000 \mathrm{~m}^{3} ; 2$ - for the lower body, with the suspended ceiling and $V_{1}=8273 \mathrm{~m}^{3} ; 3$ - same for the upper body, when $V=748 \mathrm{~m}^{3}$
Fig 3 shows the attenuation of the nonfiltered signal sound energies in both bodies of the hall.

In all cases of investigation, a distinction may be made of two attenuation periods: the initial period with still unsettled attenuation process, and the final periods with a settled attenuation process. The speed of the energy attenuation is different and the sound fields muffle according to two different exponents.

When there is no sound-absorbing material above the ceiling, the attenuation of the sound fields of both bodies has the same character in the period up to $1500 \mathrm{~ms}$, while after $1500 \mathrm{~ms}$ the attenuation becomes slower in the lower body than in the upper body. The attenuation of energy in the lower body is influenced by the attenuation in the upper body. When there is a sound-absorbing material above the suspended ceiling, the attenuation character undergoes a sharp change. The fields of both bodies muffle to $500 \mathrm{~ms}$ only, and then the attenuation of the sound field of the upper body becomes considerably slower, than that of the lower body. It means that the interaction of the sound fields differs with time and depends on whether the attenuation process is settled or not.

Fig 4 depicts the change in the relative sound energy returning to the lower body depending on the width of the opening.

The graph indicates that the sound returning to the lower body becomes more energetic with the increase in the area of the opening and is little affected

$E, \mathrm{~dB}$

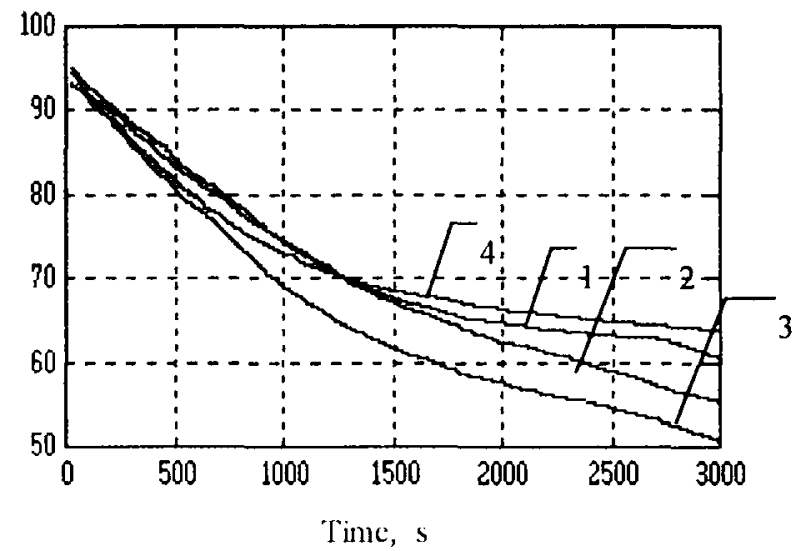

Fig 3. The attenuation of the sound energy of a nonfiltered signal in the upper and the lower bodies of the hall depending on the absorption in the upper body and the change in its volume. 1 and 2 - in the lower body $V_{1}$ and the upper body $V_{2}$ respectively, when there is no sound-absorbing material above the suspended ceiling; 3 and 4 - same with the sound-absorbing material above the suspended ceiling 


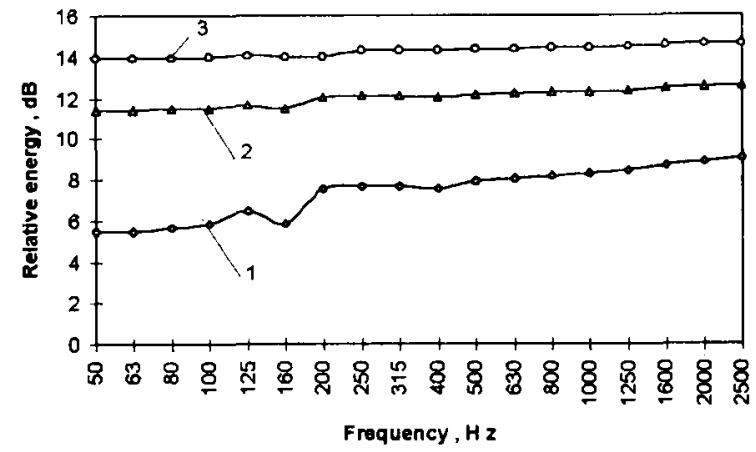

Fig 4. Dependence of the relative sound energy returning from the upper body to the lower body on the area of the opening. 1 - area of the opening $10 \mathrm{~m}^{2} ; 2-100 \mathrm{~m}^{2}$; $200 \mathrm{~m}^{2}$

on frequency. The investigations show that both the energy leaving the lower body and the upper body do not depend on frequency, therefore it is better to take the same frequency for the determination of their dependencies.

Fig 5 depicts the dependence of the energy attenuation in both bodies on the area of the opening. In all cases of investigation, the frequency value was taken as $200 \mathrm{~Hz}$, the absorption coefficient of the lower volume $\alpha_{1}$, the absorption coefficient of the upper volume $\alpha_{2}, H=4 \mathrm{~m}$ and the energy of the lower volume $\alpha_{1}$ obtained from the experimental data.

The area of the opening has a profound effect on the attenuation and interaction of energies. This is particularly noticeable at the initial stage of attenua-

$E, \mathrm{~dB}$

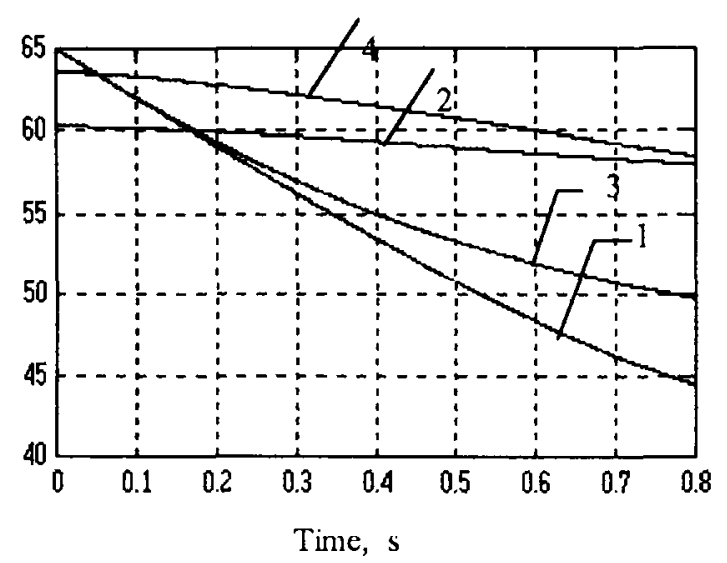

Fig 5. The dependence of the attenuation of the sound energy over $800 \mathrm{~ms}$ on the area of the opening. 1 and 2 - volume of the lower body $V_{1}$ and of the upper body $V_{2}$ when the area of the opening is $10 \mathrm{~m}^{2} ; 3$ and 4 - same with the area of $50 \mathrm{~m}^{2}$ tion, when the process is still not settled. When the area of the opening is small $\left(10 \mathrm{~m}^{2}\right)$, the energy attenuation is very rapid in the large lower body during the first $800 \mathrm{~ms}$; the attenuation in the small upper body, on the contrary, is very slow, with no attenuation up to $250 \mathrm{~ms}$. This indicates that the upper body is influenced by the sound energy of the lower volume and there is almost no attenuation when the process is still not settled. When the area of the opening is $50 \mathrm{~m}^{2}$, the attenuation of energy of the lower body is slower and that of the upper body is faster, starting with $200 \mathrm{~ms}$. The interaction of energies becomes less pronounced as the area of the opening increases.

The attenuation of energies of both bodies is different at a certain moment of time. Fig 6 demonstrates the attenuation of the sound fields over 4000 ms.

As the process becomes settled, the attenuation of energy approximately after 1000-1100 ms has an exponent character and a continuous interchange of energies takes place during the interaction of the sound fields of both bodies. As the area of the opening increases, the moment at which the settled process starts and from which the attenuation of the lower body energy acquires an exponent character, is postponed. The larger the area of the opening, the faster is the attenuation of the sound fields of both bodies, with smaller reverberation.

In Fig 7 is shown the dependence of the attenuation of energy on the change in the sound absorption of the lower body.

$E, \mathrm{~dB}$

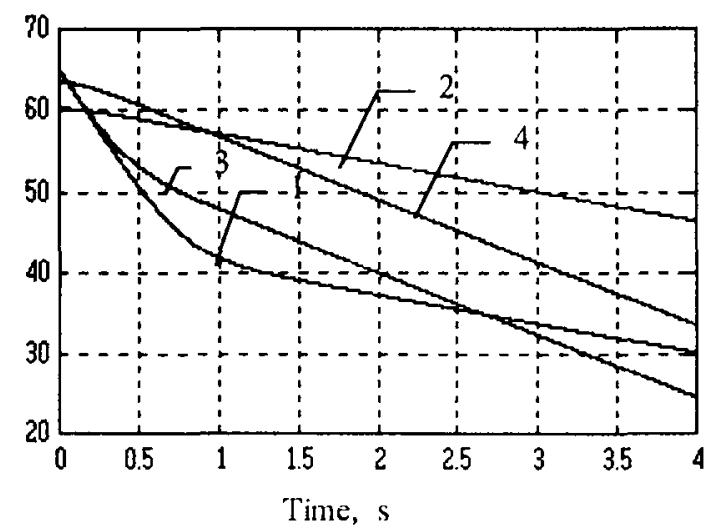

Fig 6. The dependence of the attenuation of the sound energy over $4000 \mathrm{~ms}$ on the area of the opening. 1 and 2 - volume of the lower body $V_{1}$ and of the upper body $V_{2}$ when the area of the opening is $10 \mathrm{~m}^{2} ; 3$ and 4 same with the area of $50 \mathrm{~m}^{2}$ 
$E, \mathrm{~dB}$

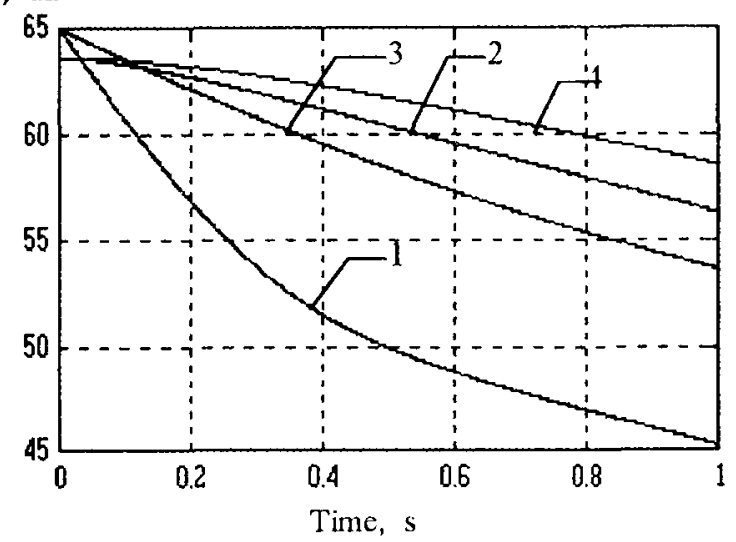

Fig 7. The dependence of the attenuation of the sound energy on the change in the sound absorption in the lower body $V_{1} .1$ and 2 - the lower body $V_{1}$ and the upper body $V_{2}$, when $\alpha_{1}=0.3 ; 3$ and 4 - same with $\alpha_{1}=0.1$

When the absorption of the lower body is small, strong interaction of the sound fields occurs at the initial stage of attenuation only. The fields of both bodies muffle slowly, because an energy interchange between both bodies takes place and the process becomes settled approximately after $800 \mathrm{~ms}$. When the absorption of the lower volume increases, the attenuation of the field of the lower body is very fast, while that of the upper body is slow. In this case, the lower body gives up much energy to the upper body and absorbs more of it. As the sound absorption of the lower body increases, the exponent character of the energy attenuation has a later starting point, while the settled phase of the process starts earlier.

The influence of the change in the volumes of the bodies on the energy attenuation is shown in Fig 8 .

When the lower body is large and the upper one is small, the attenuation of the sound energy in both bodies has almost identical exponent character. After 200-300 ms, a continuous energy interchange between both bodies starts. The attenuation of sound takes place with almost identical reverberations. When the distance from the suspended ceiling to the rigid surface is 400 $\mathrm{cm}$, i.e. when the lower body becomes smaller and the upper one becomes larger, the exponent energy attenuation in the lower body starts only after $1000 \mathrm{~ms}$, while that in the upper body - after $600 \mathrm{~ms}$ only. As long as the process is unsettled, the energy of the lower body has strong impact on the upper body during $1000 \mathrm{~ms}$. From this moment, the process becomes settled and a
E, diB

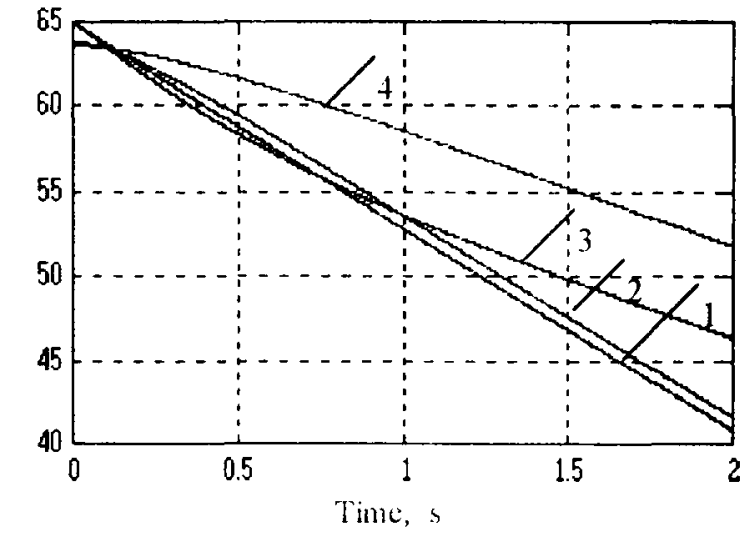

Fig 8. The dependence of the altenuation of the sound cnergy on the change in the volumes of the lower and upper bodies, when the area of the opening is $50 \mathrm{~m}^{2}$, $\alpha_{1}=0.1 ; \alpha_{2}=0.01 .1$ and 2 - the volume of the lower body $V=8273 \mathrm{~m}^{3}$ and of the upper body $V_{2}=748 \mathrm{~m}^{3} ; 3$ and $4 \cdot V_{1}=6080 \mathrm{~m}^{3}$ and $V_{2}=2992 \mathrm{~m}^{3}$

continuous interchange of energies starts. As the volume increases, the exponent attenuation of the sound field is postponed.

\section{Conclusions}

1. The experimental evidence provided by the investigations show that the dividing of the hall volume into two bodies, with the volume of one body 11 times the volume of the other, results in almost identical reverberation times of both bodies all over the frequency range, with little dependence on the change in the volume of these bodics.

2. In the acoustically-interrelated premises, both during the settled and unsettled phases of the process, it is only at certain frequencics that the sound fields muffle along different exponents with different constants. The attenuating energy of the lower body exerts stronger influenoe on the upper body only in the phase of the unsettled process.

3. The outcoming energies do not depend on frequency, while the returning ones are little dependent on it.

4. As the opening between the bodics increases, the moment at which the settled process starts and up to which more energy is given up to the upper body by the lower one, occurs sooner.

As the absorption of the lower body increases, the period over which the lower body exerts stronger influence on the upper one becomes longer and the attenuation of the lower body energy is very fast while the process is still unsellled. 
As the lower body is reduced and the upper one becomes larger, the unsettled phase of the process takes more time and during it the lower body gives up more energy to the upper body.

\section{References}

1. V. Stauskis. Rezonansiniu kabamųjų lubų jtaka salès akustiniams rodiklianıs // Statyba, 1996, Nr.3(7). V.: Technika, 1996, p. 64-69.

2. В. Фурдуев. Электроакустика. М.: Гостехиздат, 1948. $315 \mathrm{c}$.

3. Г. Голдберг. Время реверберацин в связанных помещениях // VI Всесоюзная акустическая конференция. М., 1968 , с. 1-5.

4. Х. Шчиржеский. Упрощенный метод расчета ревер берации связанных помещений // Сборник научных трудов НИИСФ, М., 1989. 38-44 с.

5. H. Kuttruff. Room Acoustics. New-York, 1991. 380 p.

Iteikta 19970207

\section{GARSO LAUKU, ATSKIRTU REZONANSINÉMIS KABAMOSIOMIS LUBOMIS, SĄVEIKA}

\section{Stauskis}

\section{S a n t rauk a}

Eksperimentais ir teoriškai nagrinèjama dvieju tūrį, atskirty rezonansinemis kabamosiomis lubomis su stačiakampès formos plyšiais tarp plokštumy garso lauku, sąveika. Eksperimentas atliktas su salès modeliu masteliu 1:25. Nustatyta, kad dviejų tūrių, kurie skiriasi net 11 kartų, reverberacijos laikai yra vienodi visame dažnių diapazone. To neturètų būti, nes smarkiai skiriantis tūriams turi smarkiai skirtis ir reverberacijos laikai, nes ju reikšmèms tūris turi lemiamos ịtakos. Tai rodo, kad tarp abiejų tūrių yra garso lauky sq̨veika. Nefiltruoto signalo energijos iki $1500 \mathrm{~ms}$ slopsta vienodai, o vèliau viršutinio mažo tūrio enrgijos slopimas yra lètesnis, negu didelio apatinio tūrio. Kada virš luby yra garsą absorbuojanti medžiaga, tai slopimo pobūdis stipriai keičiasi. Abieju tūriu energijos vienodai slopsta tik iki $500 \mathrm{~ms}$, o paskui ilgèjant laikui viršutinio tūrio energija slopsta kur kas lèčiau, negu apatinio tūrio energija. Energijų slopimas nèra eksponentinis. Apatinis ir viršutinis garso laukai buvo aprašyti formulèmis, pagal kurias apskaičiuotos abieju tūriy absorbuotosios, išejimo ir iejjimo energijos. Skaičiavimais rasta, kad energijos, išeinančios iš abiejų tūrių, nepriklauso nuo dažnio, o j abu tūrius grižtančios energijos mažai priklauso nuo dažnio.

Skaičiavimais nustatyta, kad garso lauku sąveika priklauso nuo plyšio ploto. Skaičiavimams plyšio plotas parinktas lygus visu plyšiu tarp plokštumų suminiam plotui. Nenusistovejus procesui energijos slopimas esant vienam dažniui yra daug staigesnis esant mažesniam plyšio plotui apatiniame dideliame tūryje, ir jis slopsta pagal dvi skirtingas eksponentes. Šiame laiko intervale apatinis tūris atiduoda daug energijos viršutiniam tūriui. Nusistovejjus procesui abu tūriai pasikeičia energijomis, bet slopimas vyksta su skirtingomis reverberacijomis. Didejant plyšio plotui mažeja laiko tarpas, iki kurio apatinis tūris stipriai veikia viršutini tūrị, o eksponentinis garso lauko slopimas prasideda anksčiau.

Didejant didelio apatinio tūrio absorbcijai jo garso lauko slopimas darosi staigesnis, ir jis labiau veikia viršutini garso lauką. Viršutinio tūrio energijos slopimas yra gerokai lètesnis, negu apatinio tūrio, ir apatinio tūrio absorbcijos kitimas jau turi nedidelę jtaką. Kuo didesné pirmo tūrio absorbcija, tuo vèliau prasideda eksponentinis garso lauko slopimas.

Mažèjant apatiniam tūriui ir didèjant viršutiniam tūriui eksponentinis garso lauko slopimas prasideda vèlesniu laiko momentu, o nenusistovejjus procesui energijų sqqveika tarp abieju tūrių užima platesni laiko intervalą.

Vytautas STAUSKIS. Doctor, Associate Professor. Department of Building Structures. Vilnius Gediminas Technical University, 11 Sauletekio Ave, 2040 Vilnius, Lithuania.

Doctor's degree, 1974. From 1974 at VTU Department of Building Structures. Scientific visits: Moscow Civil Engineering Institute, Sankt-Petersburg Politechnical Institute. Research interests: experimental testing of halls by primary hall models and on site, computer simulation of theoretic tasks, wave diffraction and reflections, direct sound and subjective acoustic indicators, large-dimension resonance structures, early attenuation of acoustic field and its relation to hall acoustics. 